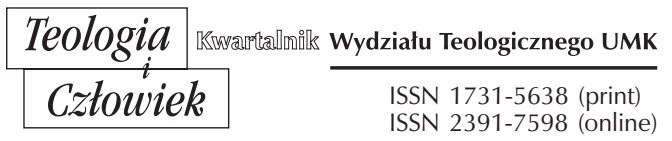

@@

52(2020)4, ss. 87-104

KS. BOGUSŁAW EDWARD MIGUT

KATOLICKI UNIWERSYTET LUBELSKI JANA PAWŁA II

BOGUSLAWMIGUT@GMAIL.COM

ORCID 0000-0002-8832-5429

\title{
OFIARNICZY WYMIAR EUCHARYSTII PODSTAWA JEJ WIĘZI Z MISTERIUM CHRYSTUSA I ŻYCIEM CHRZEŚCIJAŃSKIM
}

DOI: http://dx.doi.org/10.12775/TiCz.2020.052

\begin{abstract}
Streszczenie. Ofiara Chrystusa jest najpierw duchową ofiara Jego życia dla Ojca i braci, na krzyżu staje się ofiarą krwawą, nie przestając być ofiarą Jego bosko-ludzkiego serca (ducha), a dzięki ekonomii sakramentalnej jest ona aktualizowana na ołtarzach świata, aby przyłączyć duchowe ofiary wiernych. Całe życie chrześcijanina ma stawać się ofiarą duchową, czyli kultem w Duchu i w prawdzie w łączności z ofiarą eucharystyczną. Wszystko, co Jezus uczynił, powiedział i wycierpiał, miało na celu na nowo skierować człowieka do jego pierwotnego powołania. Ten cel przechowywany jest i przekazywany w Eucharystii, zwłaszcza dzięki jej wymiarowi ofiarniczemu. Eucharystia nie jest ozdobnikiem życia chrześcijańskiego, ale źródłem przemiany życia, a tym samym miejscem realizacji „kultu w Duchu i prawdzie $(J 4,24)$ oraz kultu Boga z Logosem i na wzór Logosu w podporzadkowaniu życia Bogu (Rz 12,1). Na tej podstawie widać wyraźnie, że ponowne odkrywanie ofiarniczego wymiaru Eucharystii przyczynia się do jej większego powiązania z misterium Chrystusa i życiem chrześcijańskim.
\end{abstract}

Słowa kluczowe: Eucharystia; ofiara Chrystusa; ofiara duchowa; logikē latreia.

Abstract. The Sacrificial Dimension of the Eucharist as the Foundation of its Connection with the Mystery of Christ and Christian Life. The sacrifice of Christ is first of all the spiritual sacrifice of His life for His Father and His brothers; on the cross it becomes a blood offering, never ceasing to be the sacrifice of His divine and human 
heart (spirit); and in the sacramental economy it is offered anew on the altars of the world so as to unite the spiritual offerings of the faithful. The whole of Christian life is meant to become a spiritual offering, that is to say, a worshiping in Spirit and in truth, united with the Eucharistic sacrifice. Everything that Jesus did, said, and suffered had the goal of redirecting man to his original calling. This goal is preserved and communicated in the Eucharist, especially thanks to its sacrificial dimension. The Eucharist is not an ornament of Christian life, but the wellspring of change in life, and thus a place for bringing about "worship in Spirit and in truth" (Jn. 4:24) and the worship of God with the Logos and, modelled on the Logos, for subordinating one's life to God. On this basis, it is clear that the rediscovery of the sacrificial dimension of the Eucharist contributes to its greater connection with the mystery of Christ and Christian life.

Keywords: Eucharist; sacrifice of Christ; spiritual sacrifice; logikē latreia.

Współczesny konwertyta i teolog Aidan Kavanagh OSB (1929-2006), pisząc o trzech głównych wyzwaniach, jakie stoją przed Kościołem, wskazuje na jego właściwą relację do świata, oderwanie kultu chrześcijańskiego od nawrócenia oraz formalno-rytualne podejście do wypełniania posługi liturgicznej przez kapłanów i wiernych świeckich ${ }^{1}$. Istotą pomocą w podjęciu tych wyzwań jest właściwe pojmowanie sakramentów, w tym zwłaszcza Eucharystii. Warto zwrócić uwagę, że Kościół nieprzerwanie podkreśla konieczność odkrywania prawdy, że Eucharystia jest przede wszystkim ofiarą. Pytaniem jednak, które się rodzi, wynika z powodu, dla którego ofiarniczy wymiar Eucharystii jest najważniejszy, a tym samym dlaczego wymiar ten pozwala widzieć w Eucharystii źródło siły i wezwanie chrześcijanina do przemiany siebie i świata oraz dlaczego łączy on Eucharystię z nawróceniem. Ostatecznie pytanie brzmi, w jaki sposób odkrycie i eksponowanie ofiarniczego wymiaru Eucharystii pozwala na pełną realizację kapłaństwa chrzcielnego i służebnego.

Jeszcze podczas Soboru Watykańskim II papież Paweł VI tematowi Eucharystii poświęcił encyklikę Mysterium fidei (3.09.1965; dalej MF), której głównym celem była obrona nauki Kościoła o transsubstancjacji. Na początku jednak tego dokumentu stwierdza: „Kościół spełniając razem

1 Por. A. Kavanagh, Religious Life and Worship, „Worship” 44 (1970), s. 196; tenże, Liturgical Needs for Today and Tomorrow, „Worship” 43 (1969), s. 493-494; tenże, Relevance and Change in the Liturgy, „Worship” 45 (1971), s. 62. 
z Chrystusem rolę kapłana i żertwy, składa cały Ofiarę Mszy świętej i cały się w niej ofiaruje”2. Nieco dalej jeszcze dobitniej podkreśla, że „Składając tę Ofiarę, Kościół uczy się składać w niej samego siebie jako ofiarę powszechną i całemu światu na zbawienie przydziela jedyną i nieskończoną moc odkupieńczą ofiary Krzyża”’3.

Jan Paweł II za najważniejszy wymiar Eucharystii uznaje jej ofiarniczość. Dzieje się tak nie tyle z powodu obecności wielorakich tendencji redukcjonistycznych w teologii Eucharystii, lecz przede wszystkim ze względu na bogactwo treści zawartych w tym wymiarze. Zawiera on bowiem dużo większą dynamikę wewnętrzną niż wymiar uczty. W Katechizmie Kościoła Katolickiego (dalej: KKK) i w encyklice Jana Pawła II Ecclesia de Eucharistia (17.04.2003; dalej EdE) najpierw omawiany jest wymiar ofiary, a w drugiej kolejności wymiar uczty. Papież ukazuje, że bez wymiaru ofiarniczego uczta staje się „spotkaniem” w wymiarze horyzontalnym.

\section{OFIARNICZY WYMIAR MISTERIUM CHRYSTUSA}

Wyjaśnienie ofiarniczego wymiaru Eucharystii zakłada najpierw przybliżenie posłannictwa, czy też misji Syna Bożego (misterium Chrystusa). W centrum tego posłannictwa znajduje się kenoza Syna Bożego, w którą wpisana jest miłość do Ojca i miłość do braci. To właśnie miłość jako dar z siebie stanowi treść misterium Chrystusa i treść Jego ofiary. Misterium Chrystusa jest misterium nowego, drugiego Adama. Jego człowieczeństwo jest „sakramentem”, czyli znakiem i narzędziem bóstwa oraz zbawienia, które przynosi. To, co było widzialne w Jego ziemskim życiu, prowadzi do niewidzialnego misterium Jego synostwa Bożego i Jego odkupieńczego posłania. Ontologiczna podstawa zbawienia i odkupienia w Chrystusie sięga tajemnicy grzechu pierworodnego w pierwszych rodzicach, a tym samym zawiera prawdę, że wszyscy ludzie są w Adamie sicut unum corpus unius hominis ${ }^{4}$. Przez tę jedność rodzaju ludzkiego wszyscy ludzie są powiązani z grzechem Adama, ale też wszyscy są objęci

\footnotetext{
2 MF 32.

${ }^{3}$ MF 33.

4 Tomasz z Akwinu, Quaestiones disputatae de malo, 4, 1.
} 
sprawiedliwością Chrystusa. Tym, co charakteryzuje grzech Adama, jest nieposłuszeństwo, skupienie włącznie na sobie i brak zaufania do Boga. W przeciwieństwie do tego misterium Chrystusa jest posłuszeństwem i zaufaniem woli Ojca i na tym polega „ofiara” życia Jezusa. On „stawszy się posłusznym aż do śmierci, i to śmierci krzyżowej" (Flp 2,8), naprawił nieposłuszeństwo Adama (por. Rz 5,19-20). Posłuszeństwo Jezusa Chrystusa, Boga i Człowieka czyni Go Kimś wyjątkowym i niepowtarzalnym. Przez posłuszeństwo stał się objawieniem miłości Ojca, przez posłuszeństwo dokonał dzieła zbawienia i odkupienia człowieka, i w końcu przez posłuszeństwo całe życie Jezusa stało się tajemnicą rekapitulacji całej historii ludzkości w Nim jako głowie. Jezus Chrystus przez swoje posłuszeństwo ukierunkował człowieka na jego pierwotne powołanie, uczynił zeń nowe stworzenie ${ }^{5}$. Z tego powodu misterium Chrystusa posiada charakter ofiarniczy. Jest ono całkowitym ofiarowaniem się Ojcu, ze względu na braci (ofiarował się za nasze grzechy), w miłości do braci. W tej ofierze przyłączył On ludzkość do siebie.

Śmierć Chrystusa na krzyżu nie była owocem przypadku, czy zbiegiem nieszczęśliwych okoliczności. Należy ona do tajemnicy zamysłu Bożego ${ }^{6}$. Bóg, posyłając własnego Syna w postaci sługi, w „postaci człowieka upadłego i poddanego śmierci $\mathrm{z}$ powodu grzechu «dla nas grzechem uczynił Tego, który nie znał grzechu, abyśmy się stali w Nim sprawiedliwością Bożą» (2 Kor 5,21)"”. Naprzeciw temu wychodzi wolna inicjatywa Jezusa, który w miłości odkupieńczej przyjął nas w naszym oddzieleniu od Boga, aż po wołanie na krzyżu w imieniu ludzkości: „Boże mój, Boże mój, czemuś Mnie opuścił?” (Mk 15,34).

Kluczem do odczytania całego życia Jezusa Chrystusa jest Jego ofiara, choć do samego wymiaru ofiary nie należy go redukować ${ }^{8}$ Ofiara ta

${ }^{5}$ Por. Cz. Bartnik, Odkupienie, usprawiedliwienie i zbawienie, w: Teologiczne rozumienie zbawienia, red. tenże, Lublin 1979, s. 34-36.

${ }^{6}$ KKK 519; por. Cz. Bartnik, Dzieło Jezusa Chrystusa. Ofiara krzyżowa, w: Jezus Chrystus ikona historii i wiary, red. R. Dziura, Lublin 2004, s. 170.

7 KKK 602.

${ }^{8}$ Bartnik stwierdza: „choć nie należy redukować Go [Jezusa Chrystusa] i Jego życia do samej ofiary, to jednak chrystologia sprzyja ofiarniczej wizji stworzenia, przenikniętego złem, grzechem i ograniczeniem [...]. Stan «rajski» stworzenia może być przywrócony tylko przez ofiarę", Dzieło Jezusa Chrystusa. Ofiara krzyżowa, s. 169. 
posiada charakter duchowy, gdyż pragnienie wypełnienia woli Ojca rodzi się w każdej chwili życia w sercu Zbawiciela, ale też „materializowane” jest w konkrecie słów i czynów, aż po przelanie krwi na krzyżu (krwawa ofiara). Życie Jezusa jest całkowitym ofiarowaniem się Ojcu, a prawdę tę wyraża w szczególny sposób Hbr 10,5-10. Od chwili wcielenia Syn Boży podejmuje Boży zamysł zbawienia i pragnie wypełnić dzieło Ojca, a więc całkowicie spełnić wolę Ojca, czyniąc z niej swój codzienny „pokarm” $(J$ 4,34). Jest to pełna komunia miłości z Ojcem. W kluczu ofiarniczym należy odczytać także początek publicznej działalności Jezusa. W kontekście chrztu Jezusa w Jordanie, udzielonego przez Jana Chrzciciela, który zobaczył i wskazał w Jezusie Baranka Bożego, gładzącego grzech świata $(J$ 1,29). Nazwanie Jezusa „Barankiem Bożym” przywołuje zarówno cierpiącego Sługę Jahwe, który w milczeniu pozwala prowadzić się na zabicie, jak i baranka paschalnego, będącego symbolem odkupienia Izraela w czasie pierwszej Paschy, a także Baranka zasiadającego na tronie, będącego symbolem zmartwychwstałego Chrystusa, „jakby zabitego”, ale żyjącego i chwalebnego, godnego „wziąć księgę i jej pieczęcie otworzyć” (por. 5,9)9. Dla całej misji Jezusa oznacza to miłość aż poza granice ludzkiej logiki, aż po złożenie w całkowitej świadomości i wolności daru ze swojego życia: „Nikt mi go nie zabiera, lecz Ja od siebie je oddaję" (J 10, 8).

Jezus najpełniej wyraził dobrowolną ofiarę z siebie podczas Ostatniej Wieczerzy, kiedy biorąc chleb starej Paschy, czyni zeń Pokarm nowej Paschy - „to jest Ciało moje, które za was będzie wydane” (Łk 22,19), a biorąc kielich dziękczynienia za stare przymierze przemienia go w kielich nowego przymierza - „To jest moja Krew Przymierza, która za wielu będzie wylana na odpuszczenie grzechów” (Mt 26,28) ${ }^{10}$. Ofiara całego życia Jezusa, tak jak znalazła swój najpełniejszy wyraz w wieczerniku, tak znajduje swoje dopełnienie i kulminację w Ogrodzie Oliwnym. Agonia w Getsemani stanowi zwieńczenie wszystkich duchowych ofiar Jezusa. Kielich Nowego Przymierza, który Jezus wziął w swoje ręce w czasie Ostatniej Wieczerzy, ofiarując siebie samego, przyjmuje następnie z rąk

9 Por. H. Witczyk, „Oto Baranek Boży zwycięży grzech świata”(J 1,29) Eucharystia a grzech świata, w: Biblia a Eucharystia, red. S. Szymik, Lublin 1997, s. 127-149.

${ }_{10}$ Por. EdE, 11; J. Kudasiewicz, Teksty ustanowienia Eucharystii, w: Biblia a Eucharystia, s. 63-82. 
swojego Ojca podczas agonii w Getsemani ${ }^{11}$. Tu Jezus Chrystus przelał pierwszą krew niebędącą jeszcze krwią biczowania, koronowania cierniem i krzyżowania, ale krwią wewnętrznej ofiary przyjęcia zbawczej woli Ojca. Choć Jezus w trwodze modlił się najpierw: „Ojcze [...] zabierz ten kielich ode Mnie”, to jednak druga część modlitwy brzmi: „Lecz nie to, co Ja chcę, ale to, co Ty" (Mk 14,36). Nie wiadomo jak długo trwał czas pomiędzy błaganiem Ojca o zabranie kielicha a wyrażeniem decyzji posłuszeństwa na cierpienie i śmierć. Ten czas „pomiędzy” jest kulminacją ofiary duchowej, przed którą Jezus prosi apostołów, aby z Nim czuwali.

Ofiara krzyża, czyli śmierć Chrystusa jest jedyną i ostateczną ofiarą za zbawienie świata, ale zawiera ona w sobie wszystkie ofiary duchowe życia Jezusa. W szczególny sposób należy ją widzieć w relacji do Jego modlitwy w Getsemani, gdzie ostatecznie wyraził w swoim sercu pragnienia oddania swego życia z miłości do Ojca i braci. W krzyżu Jezusa Chrystusa należy widzieć nie tylko okrucieństwo i ból umierania, ale przede wszystkim doprowadzenie do spełnienia ofiary duchowej, która zrodziła się w Jego Bosko-ludzkim Sercu. Śmierć na krzyżu jest tym samym ofiarą paschalną, będącą spełnieniem starej Paschy i ostatecznym odkupieniem ludzi przez niewinnego Baranka, gładzącego grzech świata, a także ofiarą Nowego i Wiecznego Przymierza, przywracającą człowiekowi komunię z Bogiem oraz dokonującą pojednania z Nim przez Krew Nowego Przymierza. Jest to ofiara jedyna, dopełniająca i przekraczająca wszelkie dotychczasowe i późniejsze ofiary. W niej współistnieje semel et semper, jest ona bowiem złożona raz jeden, a jednocześnie złożona na stałe. W niej spotykają się dwie ofiary - Ojca, który wydaje swojego Syna dla zbawienia ludzi oraz Syna, który dobrowolnie i z miłości ofiaruje swoje życie Ojcu przez Ducha Świętego. Krzyżowa ofiara Chrystusa, zawierająca w sobie całość Jego życia, jest tym, co się działo w sercu Zbawiciela, w Jego bosko-ludzkiej świadomości i nie można jej ujmować tylko jako krew przelaną na wzór przelewanej krwi nieświadomego baranka. W ofierze Jezusa Chrystusa łączy się żertwa ofiarna i kapłan, świadoma miłość Ojca i miłość braci. Ta miłość nadaje ofierze Chrystusa wartość odkupieńczą i wynagradzającą, ekspiacyjną i zadośćczyniącą. W ofierze krzyżowej Jezus zastępuje swoim

11 Por. KKK 612; S. Hahn, Czwarty kielich. Odkrywanie tajemnicy Ostatniej Wieczerzy i krzyża, Kraków 2019. 
posłuszeństwem nasze zapoczątkowane w Adamie nieposłuszeństwo, ale też wynagradza za ludzkie winy i dokonuje aktu zadośćuczynienia Ojcu za grzechy. Na pytanie, co sprawia, że żaden człowiek, nawet najświętszy, nie był w stanie wziąć na siebie grzechów wszystkich ludzi i ofiarować się za wszystkich, Kościół odpowiada: „istnienie w Chrystusie Boskiej Osoby Syna, która przekracza i równocześnie obejmuje wszystkie osoby ludzkie oraz ustanawia Go Głową całej ludzkości, umożliwia Jego ofiarę odkupieńczą za wszystkich"12. Ofiara Chrystusa ma charakter uniwersalny - obejmuje wszystkich ludzi, ale też osobowy - jest zbawieniem i odkupieniem człowieka w jego bycie indywidualnym. Ofiara życia Jezusa przyniosła zbawienie ludzkości nie tylko w znaczeniu moralnym i wzorcowym, ale głównie w znaczeniu rzeczowym i przedmiotowym.

Misterium Chrystusa to także kontynuacja i aktualizacja zbawczego dzieła Chrystusa w Kościele. Wszystko Kim Chrystus jest i czego dokonał „jest przeznaczone dla każdego człowieka, ono jest dobrem każdego człowieka"13. Uwielbiony Chrystus ze wszystkim, co przeżył i wycierpiał raz na zawsze za nas, wstawia się za nami u Boga. Nie jest On tylko doskonałym wzorem do naśladowania, ale wszystko, co „przeżył, czynił po to, abyśmy mogli przeżywać to w Nim i aby On przeżywał to w nas" ${ }^{14}$. Chrystus pragnie dopełnić swe misteria w ludziach. Pragnie On „aplikować" swoje dzieło zbawcze każdemu człowiekowi indywidualnie. Chrystus pragnie dopełnić w każdym człowieku swoje misterium paschalne. Bez misterium paschalnego, bez zesłania Ducha Świętego, nasz udział w misteriach życia Chrystusa nie byłby możliwy. Dopełnienie misterium Chrystusa w ludziach dokonuje się w Kościele, który jest trafnie oceniany jako misterium Osoby (Chrystus) w osobach (wierzący w Chrystusa) ${ }^{15}$.

Śmierć Chrystusa na krzyżu i wylanie Ducha Świętego w dniu Pięćdziesiątnicy zapoczątkowuje czas Kościoła. Chrystus żyje tu i działa w nowy sposób, który Tradycja określa mianem „ekonomii sakramen-

${ }_{12}$ KKK 616; por. J. Buxakowski, Jezus Chrystus - osoba i czyn; Teologia prawd wiary, t. 5, Pelplin 2000, s. 270-301.

13 Jan Paweł II, Redemptor hominis (4.03.1979; dalej RH), 11.

${ }^{14}$ KKK 521; por. B. Migut, Eklezjotwórczy charakter Eucharystii jako ofiary, „Seminare” 23 (2006) s. 12-16.

15 Por. Cz. Bartnik, Dzieło Jezusa Chrystusa. Chrystus „społeczny” - więź z Kościołem, w: Jezus Chrystus ikona historii $i$ wiary, s. 175-176. 
talnej”. Chrystus w ramach tej ekonomii ukazuje, uobecnia i przekazuje swoje dzieło zbawienia, a zwłaszcza misterium paschalne, za pośrednictwem sakramentów, głównie Eucharystii. Ekonomia sakramentalna jest tym samym naszym uczestnictwem w ofierze Chrystusa, życiem mocą tej ofiary oraz włączeniem wszystkich cierpień i ofiar w tę jedyną ofiarę. Celem ekonomii sakramentalnej jest przemiana człowieka na wzór Chrystusa (chrystoformizacja - przebóstwienie).

\section{OFIARA EUCHARYSTYCZNA JAKO LOGIKE LATREIA (}

Eucharystia jest kultem wraz z Logosem i na wzór Logosu, ale w konsekwencji jest to najpełniejsza odpowiedź na pytanie o to, w jakim sensie Eucharystia jest ofiarą Chrystusa, Kościoła i chrześcijanina. Zagadnieniem centralnym jest jedność ofiary eucharystycznej z ofiarą złożoną na krzyżu. Na ich jedność wskazują już słowa ustanowienia: „To jest Ciało moje, które za was będzie wydane” i „Ten kielich to Nowe Przymierze we Krwi mojej, która za was będzie wylana" (Łk 22,19-20). W Eucharystii więc Chrystus daje to samo ciało, które wydał za nas na krzyżu, tę samą krew, którą wylał „za wielu na odpuszczenie grzechów" (Mt 26,28). Eucharystia uobecnia ofiarę krzyża, jest jej pamiątką i udziela jej owoców. Jedność ofiary wypływa też z jedności, a wręcz tożsamości, przedmiotu ofiary oraz podmiotu, czyli osoby składającego. Prawdę tę bardzo precyzyjnie wyraził Sobór Trydencki, stwierdzając, że jedna i ta sama jest bowiem Hostia, ten sam ofiarujący, dziś przez posługę kapłanów, który wówczas ofiarował siebie na krzyżu, a tylko sposób ofiarowania jest inny ${ }^{16}$. Różnica w sposobie ofiarowania polega na tym, że w Eucharystii Chrystus ofiarowany jest Ojcu przez Kościół. Druga różnica jest wpisana $\mathrm{w}$ pierwszą i łączy się z sakramentalnym uobecnieniem ofiary krzyża. Polega ona na tym, że ofiara złożona przez Chrystusa na drzewie krzyża miała charakter krwawy, a ofiara eucharystyczna jest ofiarą bezkrwawą, ale rzeczywistą. Ofiara eucharystyczna nie pomnaża ofiary krzyża, nie przyczynia się do jej zwielokrotnienia,

16 DS 1743; BF 321. 
ale jest jej obecnością na sposób sakramentalny i daje możliwość jej aktualizacji.

Eucharystia jest też ofiarą Kościoła, gdyż została ona powierzona Kościołowi i ten nieustannie ją składa aż do powtórnego przyjścia Pana. W niej Kościół składa samego siebie w ofierze, ale też składa Bogu uwielbienie i dziękczynienie oraz wstawia się za żywymi i zmarłymi. W każdej Eucharystii Chrystus jest ofiarowanym Ojcu, a zarazem ofiarującym, jest ofiarą i ofiarnikiem. Ofiara krzyżowa została złożona Ojcu przez samego Chrystusa w imieniu całej ludzkości. Eucharystyczna ofiara jest składana nie tylko przez Chrystusa, ale też przez przyłączony do niego Kościół ${ }^{17}$. Ma to bezpośredni związek z kapłaństwem Chrystusa, obecnym i realizowanym na dwa sposoby - kapłaństwo chrzcielne i służebne. Różnica między nimi nie może być wyjaśniona poprzez wyższość stopnia, gdyż różnią się co do istoty. Pomimo że są realizacją jedynego kapłaństwa Chrystusa, to posiadają różne źródła sakramentalne. O ile źródłem kapłaństwa wspólnego są chrzest i bierzmowanie, o tyle źródłem kapłaństwa służebnego jest sakrament święceń. Składanie ofiary eucharystycznej wiąże się najpierw z posługą prezbiterów i biskupów, którzy na mocy sakramentu święceń uobecniają Chrystusa - Głowę Mistycznego Ciała wśród zgromadzonego Kościoła. Dekret Presbyterorum ordinis (DP) wyraża tę prawdę słowami „Przez posługę prezbiterów dokonuje się duchowa ofiara wiernych w zjednoczeniu z ofiarą Chrystusa, jedynego Pośrednika. Tę zaś ofiarę składa się bezkrwawo i sakramentalnie w Eucharystii przez ich ręce w imieniu całego Kościoła aż do czasu przyjścia samego Pana"18. Istotne jest więc współskładanie Ofiary eucharystycznej przez tych, którzy mają udział w kapłaństwie Chrystusa na mocy sakramentu chrztu i bierzmowania. Współskładanie ze strony wiernych polega na budzeniu w sobie i włączaniu w ofiarę Chrystusa swych duchowych ofiar. Tak jak bez posługi kapłaństwa służebnego krzyżowa ofiara Chrystusa nie mogłaby być sakramentalnie obecna, tak też duchowa ofiara nie mogłaby być $\mathrm{w}$ nią włączona. Podsumowując, należy stwierdzić, że wszyscy zgromadzeni

17 Por. A.M. Sicari, Eucharystia - ofiara Chrystusa, Kościoła i ludzkości, w: Eucharystia (Kolekcja Communio 1), s. 285-294; J. Grześkowiak, Oto wielka tajemnica wiary, Poznań 1987, s. 180-184.

18 DP 2. 
na sprawowanie ofiary eucharystycznej (kapłan i wierni) składają ofiary duchowe. Kapłani działający in persona Christi składają sakramentalnie uobecnioną ofiarę Chrystusa Ojcu, włączając w nią duchowe ofiary zgromadzonych na sprawowanie Eucharystii.

Podstawowym pojęciem dla ujmowania Eucharystii jako ofiary Kościoła i chrześcijanina jest „ofiara duchowa”. Istnieje wiele wyjaśnień tego pojęcia, ale najprościej można je wyjaśnić przez odwołanie się do życia Jezusa Chrystusa i Jego nauczania, zawartego w J 4 oraz do Pawłowego nawoływania, aby chrześcijanie traktowali swe życie jako ofiarę ku czci Boga. Jezus w rozmowie z Samarytanką stwierdza najpierw, że kult Boga, który On zapoczątkowuje jest kultem „w Duchu i prawdzie” (J 4,24). Oznacza to, że kult chrześcijański jest kultem serca, czyli jest kultem duchowym, ale jest też kultem w Duchu Świętym oraz w prawdzie, czyli w Chrystusie, przez Chrystusa i na wzór Chrystusa. Wzór ten pokazuje Jezus nieco dalej, gdy stwierdza: „Moim pokarmem jest wypełnić wolę Tego, który Mnie posłał, i wykonać Jego dzieło" (J 4,34). Pełnie woli Ojca jest dla niego wszystkim, treścią i pokarmem życia, ale też najdoskonalszym sposobem kultu Ojca. Św. Paweł, mając przed oczyma taką postawę Jezusa, zwraca się do wierzących: „A zatem proszę was, bracia, przez miłosierdzie Boże, abyście dali ciała swoje na ofiarę żywą, świętą, Bogu przyjemną, jako wyraz waszej rozumnej służby Bożej” (Rz 12,1).

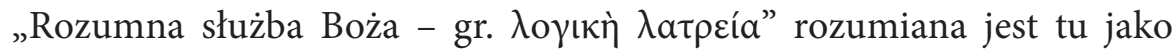
służba Bogu, czyli kult w łączności z Chrystusem jako Logosem i na Jego wzór, czyli w szukaniu i wypełnianiu woli Ojca. Kult Ojca „w łączności z Logosem”, który jako jedyny w doskonały sposób uwielbił Ojca, wypełniając Jego wolę oraz „na wzór Logosu”, czyli w ciągłym, poszukiwaniu woli Ojca i pragnieniu spełniania tej woli jest najprostszą i najbardziej wymowną definicją Eucharystii. Łączność z Logosem ma wymiar sakramentalny, ale „kult na wzór Logosu” odnosi się do konkretu naszego życia.

Chrześcijanie nie posiadają innych ofiar, poza tą jedyną, złożoną raz na zawsze Ofiarę życia Jezusa. Szukanie i wypełnianie woli Ojca jest ofiarą duchową, która ma być składana w każdej Eucharystii. Bez niej Eucharystia byłaby tylko uobecnianiem ofiary Chrystusa, ale nie byłaby naszą ofiarą, a tym samym byłaby oderwana od naszego życia. Byłaby kultem, jaki Jezus Chrystus składa Ojcu, ale nie byłaby kultem, jakim my wraz z Chrystusem uwielbiamy Ojca. 
Ofiara duchowa wpisana jest w życie chrześcijańskie, w jego wymiar moralny i duchowy. Kościół utożsamia życie moralne z kultem duchowym, łącząc je też z Ofiarą eucharystyczną. „Składamy «ciała swoje na ofiarę żywą, świętą, Bogu przyjemną» (Rz 12,1) w Ciele Chrystusa, które tworzymy, i w komunii z Ofiarą eucharystyczną. [...] Życie moralne, podobnie jak całość życia chrześcijańskiego, ma swoje źródło i swój szczyt w Ofierze eucharystycznej" ${ }^{19}$. Ofiara duchowa jako wypełnienie woli Ojca, czyli powierzenie mu drogi - zaufanie, całkowite oddanie się Jego miłości, jest zaś możliwa dzięki uczestnictwie w ofierze eucharystycznej ${ }^{20}$.

Eucharystia nie ogranicza się jednak do samego wymiaru ofiarniczego, gdyż jest ona uświęceniem i obdarowaniem. Ponadto ofiarniczy wymiar Eucharystii nie wyraża się wyłącznie w składaniu „ofiary duchowej”, gdyż jest ona także ofiarą uwielbienia i dziękczynienia za dzieło stworzenia i odkupienia. Ostatecznie jednak należy stwierdzić, że liturgia jako całość jest najpierw obdarowaniem i uświęceniem w Chrystusie, ale ostatecznie spełnia się w kulcie, czyli pełniejszym oddaniu kultu Ojcu w Chrystusie przez życie bardziej podporządkowane woli Bożej. Podobnie Eucharystia, dając udział w życiu Chrystusa, co wyrażają słowa Jezusa wypowiedziane do Piotra przy obmywaniu nóg podczas Ostatniej Wieczerzy: „jeśli cię nie umyję, nie będziesz miał udziału ze Mną" (J 13,8b), jest przede wszystkim miejscem składania duchowych ofiar jako aktów „kultu w Duchu i w prawdzie" (J 4,24), a tym samym miejscem przemiany życia i świata.

\section{PRZESTRZEŃ LITURGICZNA W SŁUŻBIE EUCHARYSTII JAKO OFIARY}

Przestrzeń liturgiczna jest także wyrazem ofiarniczego wymiaru Eucharystii w aspekcie składania „duchowych ofiar”. Zagadnienie to znajduje swój wyraz przede wszystkim w Ogólnym wprowadzeniu do Mszału Rzymskiego ${ }^{21}$ (OWMR), we wprowadzeniu do Obrzędów poświęcenia

19 KKK 2031; por. J. Szlaga, Eucharystia - ofiara Nowego Przymierza, w: Eucharystia - miłość i dziękczynienie, red. W. Słomka, A.J. Nowak (Homo meditans, t. IX), Lublin 1992, s. 19.

${ }^{20}$ KKK 2100.

${ }^{21}$ Ogólne wprowadzenie do Mszału Rzymskiego. Z trzeciego wydania Mszału Rzymskiego (Rzym 2002), Poznań 2004. Omówienie wprowadzenia: por. A. Klocek, Nowe 
$K_{\text {Kościoła }}^{22}$ (OPK) i wprowadzeniu do Obrzędów poświęcenia ołtarza ${ }^{23}$ (OPO). Ofiarniczy wymiar Eucharystii objawia się już w samym znaczeniu budynku kościoła, przeznaczonego do jej sprawowania oraz w centralnym umiejscowieniu w nim ołtarza, na którym Eucharystia jest sprawowana. Centralne usytuowanie ołtarza charakteryzuje wszystkie obrządki liturgiczne, a przesłonięcie go ikonostasem w Kościołach Wschodnich jeszcze mocniej uwypukla jego znaczenie. W liturgii rzymskiej, ołtarz zajmuje miejsce centralne w przestrzeni liturgicznej i jest „fizycznym” centrum całego zgromadzenia.

Poszczególne obrzędy poświęcenia ołtarza eksponują wymiar ofiarniczy Eucharystii. Pierwszym z nich jest namaszczenie ołtarza, przez co staje się on symbolem Chrystusa, czyli „Namaszczonego” przez Ojca Duchem Świętym i ustanowionego Najwyższym Kapłanem, „aby na ołtarzu swego Ciała złożył w ofierze swoje życie za zbawienie wszystkich" ${ }^{24}$. Na ołtarz jako symbol Chrystusa i Jego krzyżowej ofiary jeszcze dobitniej wskazuje wprowadzenie do $\mathrm{OPO}^{25}$. Centralną prawdą, potwierdzoną przez Ojców Kościoła, jest Chrystus, który „stał się żertwą, kapłanem i ołtarzem własnej ofiary”. OPO powołuje się następnie na List do Hebrajczyków, gdzie Chrystus ukazany jest jako „Arcykapłan i żywy Ołtarz niebieskiej świątyni” (Hbr 4,14; 13,10) oraz na Księgę Apokalipsy, gdzie jest On przedstawiony jako „Baranek zabity, którego ofiarę święty Anioł przenosi na ołtarz w niebie” (Ap 5,6) ${ }^{26}$.

Spalanie kadzidła na ołtarzu wyraża przede wszystkim prawdę o tym, że ofiara Chrystusa, uobecniana w Eucharystii, „wznosi się do

elementy Institutio generalis trzeciej typicznej edycji Missale romanum, „Liturgia Sacra” 7 (2001), s. 263-282.

${ }^{22}$ Obrzędy poświęcenia Kościoła i ołtarza, wyd. wzorcowe, Katowice 2001, s. $25-37$.

${ }^{23}$ Tamże, s. 114-127. Na temat ołtarza i jego symboliki ofiarniczej por. J. Decyk, Dedykacja Kościoła i ołtarza, w: Mszał księga życia chrześcijańskiego, red. B. Nadolski, Poznań 1989, s. 181-193; P. Sczaniecki, Ottarz i duch ofiary, RBL 48 (1995), s. 225-231; Cz. Krakowiak, Dedykacja ołtarza wedtug Pontyfikału Rzymskiego z 1977 r., RBL 34(1981), s. 361-372; K. Lilijka, Natura i godność ołtarza według Pontyfikału rzymskiego, „Liturgia Sacra” 10 (2004), s. 43-54.

${ }^{24}$ OPK 16.

${ }^{25}$ Por. OPO 1 i 4.

${ }^{26}$ OPO 1. 
Boga jako słodka woń"27. Bardzo doniosłe znaczenie dla ukazania ofiarniczego wymiaru Eucharystii w aspekcie eklezjalnym ma stwierdzenie podkreślające doniosłość okadzenia zgromadzonego Ludu Bożego jako żywej świątyni, „w której każdy wierny jest duchowym ołtarzem”28. Prawda o ochrzczonym jako duchowym ołtarzu została też wyrażona w OPO: "Skoro Chrystus, Głowa i Nauczyciel, jest prawdziwym ołtarzem, to również Jego członkowie i uczniowie stanowią duchowe ołtarze, na których Bogu składa się ofiarę życia święcie prowadzonego"29. Składanie duchowych ofiar przez wiernych („duchowe ołtarze”) jest tu bardzo mocno powiązane z prawdą o Eucharystii jako ofierze Kościoła. Chrystus, uobecniający swą krzyżową ofiarę, przyłącza do niej duchowe ofiary wiernych, czyni z nich „duchowe kamienie” i „buduje ołtarz Kościoła” 30 . Własną krwią przypieczętowali swoje ofiary duchowe męczennicy, których relikwie są złożone w ołtarzu ${ }^{31}$. Także ich ofiary są związane z ofiarą Chrystusa („ofiara członków [Mistycznego Ciała] wywodzi swój początek z ofiary Głowy”) oraz z ofiarą eucharystyczną („wypada nad ich grobami wznosić ołtarze albo składać ich relikwie w ołtarzach tak, by ich zwycięskie ofiary znalazły się w tym miejscu, gdzie Chrystus jest ofiarą") ${ }^{32}$.

Nakrycie ołtarza również wskazuje nań jako na miejsce ofiary eucharystycznej oraz stół Pański, „do którego wszyscy wierni przychodzą z radością, by posilić się Bożym pokarmem, czyli Ciałem i Krwią ofiarowanego Chrystusa”33. OPO definiuje wręcz ołtarz jako stół „ofiary i uczty, na którym kapłan, przedstawiający Chrystusa Pana, dokonuje tego samego, co Chrystus uczynił i przekazał swoim uczniom, aby czynili na Jego pamiątkę" 34 .

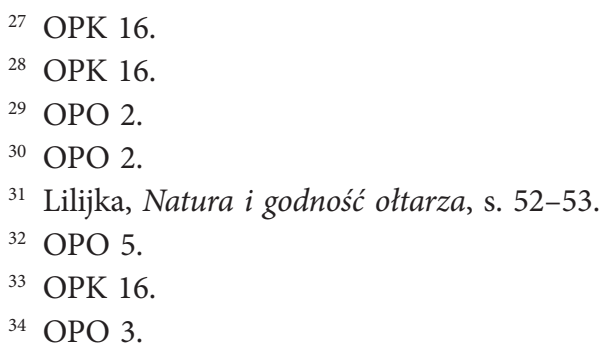




\section{UCZESTNICTWO W OFIERZE EUCHARYSTYCZNEJ JAKO WYRAZ logikē latreia}

Sprawowanie Eucharystii i uczestnictwo w niej ukazują jej wymiar ofiarniczy. OWMR na ofiarniczy wymiar Eucharystii zwraca uwagę w części omawiającej przyniesienie i złożenie darów chleba i wina, ale przede wszystkim centralny moment Eucharystii, jakim jest modlitwa eucharystyczna, a w niej fragment zwany właśnie „ofiarowaniem”. Wiele treści ubogacających nasz temat zawierają teksty euchologijne, a zwłaszcza kolekty mszalne, zawarte w samym mszale. OWMR nie pozostawia żadnych wątpliwości co do ofiarniczego wymiaru Eucharystii. Mówi się tu o „darach na ofiarę", czyli o chlebie i winie, przynoszonych przez wiernych i składanych na ołtarzu. W tym miejscu akcentuje się też „wymowę i duchowe znaczenie" tego obrzędu ${ }^{35}$.

Okadzenia wskazują również na ofiarniczy wymiar Mszy. OWMR zaznacza, że podczas liturgii na wejście okadza się krzyż i ołtarz. Są to dwa elementy związane $\mathrm{z}$ ofiarą Chrystusa i Kościoła. Podczas składania darów ofiarnych podkreśla się, że okadzenia dotyczą darów, krzyża, ołtarza, kapłana i ludzi ${ }^{36}$. Wszystko to bardzo wyraźnie wskazuje, że okadzenie dotyczy ofiary i ma w dużym stopniu wydźwięk ofiarniczy. Dary składane na ołtarzu symbolizują dary duchowe przyniesione przez wiernych. Krzyż przypomina tę jedyną ofiarę, która została złożona na krzyżu Jezusa Chrystusa. Ołtarz to miejsce składania ofiary. Kapłan to ten, który uobecnia Chrystusa składającego siebie w ofierze i lud to ten, który darach chleba i wina zawarł swoje ofiary duchowe, czyli pragnienie całkowitego posłuszeństwa woli Ojca na wzór Chrystusa. Poznanie woli Ojca jest możliwe dzięki proklamacji Słowa Bożego, a zwłaszcza Ewangelii, której księga jest również okadzana podczas liturgii słowa. Tego znaczenia ofiarniczego dopełnia okadzenie podczas ukazywania Hostii i kielicha po konsekracji.

OWMR, mówiąc u sprawowaniu Mszy i uczestnictwie w niej stwierdza, że całe zgromadzenie wiernych jednoczy się z Chrystusem

35 OWMR 73.

${ }^{36}$ OWMR 75. 276. 
„W głoszeniu wielkich dzieł Bożych i w składaniu Ofiary" ${ }^{37}$. Wymowę ofiarniczą eksponuje jeszcze mocniej następny punkt OWMR:

Kościół dąży do tego, aby wierni ofiarowali nie tylko niepokalaną Hostię, lecz by się także uczyli samych siebie składać $\mathrm{w}$ ofierze i aby z dnia na dzień przez pośrednictwo Chrystusa coraz ściślej się jednoczyli z Ojcem i między sobą, by w końcu Bóg był wszystkim we wszystkich ${ }^{38}$.

Celem obrzędów wstępnych jest skupienie na tym, co da możliwość poznania woli Ojca przez słuchanie Słowa Bożego i godnego włączenia się w ofiarę eucharystyczną. Uczta słowa, której główną cześć stanowią

czytania wzięte z Pisma Świętego [...]. W czytaniach, które homilia wyjaśnia, Bóg przemawia do swego ludu, ujawnia misterium odkupienia i zbawienia oraz dostarcza wiernym duchowego pokarmu. Sam Chrystus przez swoje słowo jest obecny pośród wiernych. Lud przyswaja sobie to Boże słowo w milczeniu i przez śpiewy oraz przyłącza się do niego przez wyznanie wiary. Nakarmiony tym słowem zanosi modlitwę powszechną w potrzebach całego Kościoła i za zbawienie całego świata ${ }^{39}$.

Liturgia Słowa zakłada wcześniejszą osobistą medytację Pisma Świętego oraz osobisty i wspólnotowy wysiłek orientowania swojego życia według objawionej w nim woli Bożej. Sama, będąc świętowaniem obecności Chrystusa w Jego Słowie i wsłuchiwaniem się w Jego naukę, łączy w sobie aspekt celebracyjny i egzystencjalny. Z niej też każdy uczestnik czerpie inspirację do wejścia w ucztę ofiary i komunii oraz moc do codziennego życia. Słowa te należy w praktyce interpretować następująco: Liturgia Słowa stawia uczestników w konkretnym dniu, w konkretnej sytuacji, podczas konkretnej celebracji wobec żywego słowa Boga. To słowo jest skierowane bezpośrednio do każdego uczestnika, przeżywającego w konkretny sposób swoje życie. Bóg objawia mu swoją wolę, tak jak objawiał ją Jezusowi Chrystusowi każdego dnia Jego życia. Bóg w ten sposób zaprasza człowieka do wypełnienia Jego woli, czyni go współpracownikiem swojej Opatrzności, zostawiając mu wolną decyzję i możli-

\footnotetext{
37 OWMR 78.

38 OWMR 79.

39 OWMR 55.
} 
wość dokonania wolnego wyboru. Ilekroć człowiek poznaje wolę Ojca, na skutek wsłuchania się w Jego słowo i przyjęcia go ochotnym sercem, a zarazem decyduje się ją pełnić w konkretnej sytuacji swojego życia, składa Bogu ofiarę duchową. Owa ofiara duchowa jest istotna w każdej celebracji Eucharystii. Ta ofiara duchowa jest podporządkowaniem „tu i teraz życia człowieka", jego sytuacji egzystencjalnej woli Ojca. Jest ona „Ogrodem Oliwnym” każdego uczestnika i jego krzyżem.

W liturgii eucharystycznej najpierw, podczas przygotowania darów, przynosi się do ołtarza chleb i wino z wodą, które Chrystus wziął w ręce ${ }^{40}$. Następnie, w czasie modlitwy eucharystycznej, składane jest Bogu dziękczynienie za całe dzieło zbawienia, a złożone dary przeistaczają się w Ciało i Krew Chrystusa, które podczas komunii stają się pokarmem ${ }^{41}$. Ofiara duchowa, podjęta w czasie liturgii Słowa, zostaje „zmaterializowana”, wyrażona w znaku, gdy na ołtarz przynoszone są dary chleba i wina. Chleb i wino łączą $\mathrm{w}$ sobie wymiar paschalny sprawowanej ofiary Chrystusa i ofiary duchowe uczestników Eucharystii. W chlebie i winie, zgodnie z wolą Chrystusa wyrażone są najważniejsze dary, czyli ofiary duchowe uczestników, polegające na chęci nawrócenia i życia dla Boga, do czego wzywało usłyszane słowo Boże.

Podczas wypowiadanego przez kapłana opisu ustanowienia Eucharystii „moc słów i działania Chrystusa oraz moc Ducha Świętego sprawia, że pod postaciami chleba i wina uobecnia się sakramentalnie Ciało i Krew Chrystusa, Jego ofiara złożona na krzyżu raz na zawsze"42. W anamnezie Kościół „wspomina mękę, zmartwychwstanie i chwalebne wniebowstąpienie Jezusa Chrystusa” oraz „przedstawia Ojcu jako własną ofiarę Jego Syna, który nas z Nim pojednał”43. Za moment ofiarowania uznaje się najczęściej właśnie to przedstawienie Ojcu ofiary Chrystusa. $\mathrm{O}$ wiele bardziej znaczący jest jednak sam moment konsekracji - przemiany darów chleba i wina składanych w czasie Eucharystii. Konsekracja jest przede wszystkim wyrazem aktualizacji ciała i krwi Chrystusa w darach (symbolach duchowej ofiary) zgromadzonych uczniów. Aktualizacja ta jest

\footnotetext{
40 Por. B. Migut, Znaki misterium Chrystusa, Lublin 1996, s. 222.

${ }^{41}$ OWMR 72.

${ }^{42}$ KKK 1353.

${ }^{43}$ KKK 1354.
} 
wynikiem dokonanej przez Chrystusa swoistej identyfikacji Jego własnej ofiary (swego ciała i krwi) z ofiarami uczniów (chleba i wina). Przeistoczenie odnosi się więc nie tylko do chleba i wina, lecz oddziałuje także na składających ofiarę, których „ofiara duchowa”, znak przemienienia się przez odnowienie umysłu, w celu rozpoznania, jaka jest wola Boża” (Rz 12,2), zostaje włączona w ofiarę Chrystusa. Można więc stwierdzić, że chleb i wino ofiarowane jako symbole duchowej ofiary chrześcijanina stają się sakramentem ofiary Chrystusa. Duchowa ofiara ucznia Chrystusa przez znak sakramentalny łączy się z ofiarą Pana, tworząc z nią jedną całość. Jezus Chrystus, mocą Ducha Świętego, przemienia dary chleba i wina w swoje Ciało i Krew, łączy je w sakramentalny sposób ze swoją jedyną ofiarą i składa Ojcu Niebieskiemu jako tę ofiarę, która jedyna ma moc zbawienia i jedyna w pełni podoba się Ojcu. Jest ona bowiem złożona z całego serca i bez reszty, raz na zawsze. I tak ofiara chrześcijanina, która jest zawsze „nie do końca” i zawsze niesie w sobie niedoskonałość, staje się na sposób sakramentalny ofiarą Tego, który do końca i bez reszty, raz na zawsze złożył swoją ofiarę. Tak oto Jego ofiara staje się moją ofiarą chrześcijanina. Ofiara Chrystusa staje się ofiarą Kościoła, a jednocześnie jest ona ofiarą, która włącza człowieka w zbawienie świata i pozwala mu „dopełniać braku udręk Chrystusa” (Kol 1,24).

Otrzymanie komunii w chlebie, który był znakiem ofiary chrześcijanina, a teraz stał się Ciałem Pańskim, oznacza, że wewnętrzna ofiara uczestnika celebracji zostaje potwierdzona (uczyniona ważną) dzięki uczestnictwu w ofierze Chrystusa ${ }^{44}$. Komunia jest sakramentalnym zjednoczeniem z Chrystusem i udziałem w Jego Ofierze.

$\mathrm{Na}$ zakończenie warto zwrócić uwagę, że powyższą interpretację Eucharystii można znaleźć u Benedykta XVI w jego adhortacji Sacramentum Caritatis z 22 lutego 2007 r. (SC). Papież pisze:

Celebracja eucharystyczna jawi się tutaj w całej swej mocy jako źródło i szczyt kościelnej egzystencji, w miarę jak wyraża równocześnie czy to genezę, czy spełnienie nowego i definitywnego kultu, logiké latreía [...] (Rz 12,1). Te słowa ukazują obraz nowego kultu jako całkowitą ofiarę złożoną z własnej osoby $\mathrm{w}$ komunii z całym Kościołem. [...] Nauka katolicka stwierdza bowiem, że Eucharystia jako ofiara Chrystusa, jest

${ }^{44}$ Por. Migut, Znaki misterium Chrystusa, s. 224. 
także ofiarą całego Kościoła, a więc wiernych. Nacisk położony na ofiarę (sacrificium) oznacza tutaj całe egzystencjalne bogactwo, wciągnięte w przekształcenie naszej ludzkiej rzeczywistości, pochwyconej przez Chrystusa (por. Flp 3,12) ${ }^{45}$.

\section{BIBLIOGRAFIA}

Bartnik Cz., Odkupienie, usprawiedliwienie i zbawienie, w: Teologiczne rozumienie zbawienia, red. tenże, Lublin 1979.

Bartnik Cz., Dzieło Jezusa Chrystusa. Chrystus „społeczny” - więź z Kościołem, w: Jezus Chrystus ikona historii i wiary, red. R. Dziura, Lublin 2004, s. 175-179.

Bartnik Cz., Dzieło Jezusa Chrystusa. Ofiara krzyżowa, w: Jezus Chrystus ikona historii i wiary, red. R. Dziura, Lublin 2004, s. 169-172.

Buxakowski J., Jezus Chrystus - osoba i czyn (Teologia prawd wiary, t. 5), Pelplin 2000.

Decyk J., Dedykacja Kościoła i ołtarza, w: Mszał księga życia chrześcijańskiego, red. B. Nadolski, Poznań 1989, s. 181-193.

Grześkowiak J., Oto wielka tajemnica wiary, Poznań 1987.

Hahn S., Czwarty kielich. Odkrywanie tajemnicy Ostatniej Wieczerzy i krzyża, Kraków 2019. Kavanagh A., Liturgical Needs for Today and Tomorrow, „Worship” 43 (1969), s. 488-495.

Kavanagh A., Religious Life and Worship, „Worship” 44 (1970), s. 194-204.

Kavanagh A., Relevance and Change in the Liturgy, „Worship” 45 (1971), s. 58-72.

Klocek A., Nowe elementy Institutio generalis trzeciej typicznej edycji Missale romanum, „Liturgia Sacra” 7 (2001), s. 263-282.

Krakowiak Cz., Dedykacja ołtarza wedlug Pontyfikatu Rzymskiego z 1977 r., RBL 34 (1981), s. 361-372;

Kudasiewicz J., Teksty ustanowienia Eucharystii, w: Biblia a Eucharystia, red. S. Szymik, Lublin 1997, s. 63-82.

Lilijka K., Natura i godność ołtarza według Pontyfikału rzymskiego, „Liturgia Sacra” 10 (2004), s. 43-54.

Migut B., Znaki misterium Chrystusa, Lublin 1996.

Migut B., Eklezjotwórczy charakter Eucharystii jako ofiary, „Seminare” 23 (2006), s. 11-28

Sczaniecki P., Oltarz i duch ofiary, RBL 48(1995), s. 225-231;

Sicari A.M., Eucharystia - ofiara Chrystusa, Kościoła i ludzkości, w: Eucharystia (Kolekcja Communio 1), s. 285-294;

Szlaga J., Eucharystia - ofiara Nowego Przymierza, w: Eucharystia - miłość i dziękczynienie, red. W. Słomka, A.J. Nowak (Homo meditans, t. 9), Lublin 1992, s. 13-19;

Witczyk H., „Oto Baranek Boży zwycięży grzech świata”(J 1,29) Eucharystia a grzech świata, w: Biblia a Eucharystia, red. S. Szymik, Lublin 1997, s. 127-149.

${ }^{45}$ SC 70. 